
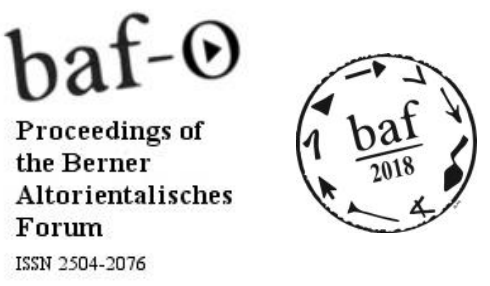

Abstract
Xiaojun Chai
Beijing Normal University/FU Berlin
DOI: http://dx.doi.org/10.22012/baf.2018.03

\title{
Silk and Horses: Trade and Tribute between the Qing Dynasty and the Kazakh Khanate
}

This paper seeks to analyze the ways in which the exchange of silk for horses impacted trade regulations along the Silk Road, thus leading to a rupture in Chinese economic policy. Exchanges between the Qing Dynasty and the Kazakh Khanate were carried between 1759 and 1796, having begun after the Qianlong Emperor vanquished the Dzungar Khanate, which determined the khan of the Kazakhs to swear allegiance to the Emperor. As the Qing Dynasty had up until that point been both politically and economically isolationist, this marked a radical change in its foreign policy.

The relation established between emperor and khan is known as chao gong mao yi (朝贡贸易) and is usually translated as vassalage, owing to the similarities with the European concepts, but it also involves the offering of tributes. Traditionally, when discussing the Qianlong Emperor's decision to consolidate trade with its new vasal, scholars have tended to favor one of three narratives: the first sees this exchange in the same light as the economic relations between the imperial capital and any of China's provinces, and therefore focuses on the inclusions character of the policy. The second considers the exchange of horses for silk as representing the immediate, dire needs of the two political leaders; while the Khan and his court required fine materials for their own prestige, the Emperor's armies had an urgent need for horses in the fight against the rebellious Uighurs in Altishahr. The third postulates that engaging in trade would have allowed the isolated Qing to secure their borders.

Rather than fully accepting or discarding any of these narratives, a more nuanced position can be gained. We can do this by understanding the implications of vassalage and tribute in close connection with the way in which the whole regional economic policy was modeled around it. I will look at the ways in which chao gong mao yi and its economical meaning were defined in Chinese archives. This will allow us to better understand their interconnected evolution. The Chinese archives that I will look at are formed of two types of documents: the first of these, the jun ji chu lu fu zou zhe (军机处录副奏折), are extensive reports on the affairs of the army, including their military actions and tactics, the power struggles 
between officers, and the rations needed to feed and supply the troops, to name only a few; the second, the Qianlong chao shi lu (乾隆朝实录), are concise reports that describe in minute detail the affairs of the imperial court. When taken together, these materials paint a vivid picture of the social, economic, and political life of late eighteenth-century China. From these sources we can see that the Qing opted for a sort of tribute trade which made a compromise on the tariff. This shows that while the Qing were clearly making some profit, the need of supplying the armies with horses in Alishahr was

more important, and they were therefore forced to maintain their conservative economic policy.

These materials offer new information which scholars that have tried to defend one of the three narratives in particular have so far neglected. Most important amongst these are two interconnected aspects: on one hand, by investigating how the Silk Road was rebuilt, we see that two different projects were used for the north and for the south. This led to the displacement of the economy towards the north, as it connected several important cities and trade hubs, such as Suzhou、Suzhou . By ignoring the regional impact, historians have tended to downgrade or neglect the changes that this disruption brought to the course of trade. On the other hand, this very separation is the thing that destabilized the region. It caused local unrest, uprisings and separatist tendencies. These episodes of local unrest forced a rethinking of the entire imperial economic policy.

The Qianlong Emperor's policy was never expansionist, neither in territorial nor in economic terms. While they were clearly aware of the importance of forging a strong relationship with their northern Kazakh neighbors, they never had any ambitions to expand towards inner Asia. We can observe this in the way in which the economic policy that they initiated with the Khanate later form the basis for the trade routes with Russia through Qiaketu. These routes would economically drain the Kazahks in the long term. That China was not expansionist at this point can easily be observed from the fact that it hesitated to break out of its traditional approach even when the Kazakhs were weakened, so it was the Russian who eventually absorbed them.

To conclude, it can be said that a new understanding of China's attitudes as a regional actor during the period of Qing Dynasty can be gained by looking at smaller units and understanding how different types of regional or local economic policies evolved together. Quite often, these impacted not only interconnected regions but the empire as a whole. As we have seen, the exchange of silk for horses along the Silk Road is just one such example. Given the rich material that is available in the Chinese archives, many other aspects could be studied. 